\title{
Evaluation of dry matter intake, average daily gain and faecal nitrogen excretion predicted by the Cornell Net Carbohydrate and Protein System with different beef cattle breeds fed in China
}

\author{
X.X. Xie ${ }^{1}$, Q.X. Meng ${ }^{1}$, L.P. Ren ${ }^{1,3}$, J.P. Du² and M. Lin ${ }^{1}$ \\ ${ }^{1}$ China Agricultural University, College of Animal Science and Technology, State Key Laboratory of Animal Nutrition \\ Beijing 100193, P.R. China \\ ${ }^{2}$ Yangtze University, College of Animal Sciences, Jingzhou 434025, P.R. China
}

KEY WORDS: CNCPS model, dry matter intake, daily gain, faecal $\mathrm{N}$ excretion, beef cattle

Received: 22 June 2012

Revised: 4 July 2013

Accepted: 20 November 2013

${ }^{3}$ Corresponding author: e-mail:

renlp@cau.edu.cn

\begin{abstract}
This study was conducted to evaluate the predictions of dry matter intake (DMI), average daily gain (ADG), and faecal nitrogen (N) excretion by the Cornell Net Carbohydrate and Protein System Version 6.1.26 (CNCPSv6) in China. A total of 71 bulls from two imported breeds, Limousin and Simmental, and three local breeds: Luxi, Jinnan and Qinchuan were selected in China. Data required by the CNCPSv6 model were collected, and model predictions were generated for animals of each breed. The regression equation between observed and predicted DMI for these cattle was: $Y_{\text {OBS }}=0.93 X_{\text {CNCPS }}+0.48\left(R^{2}\right.$ $=0.94 ; P<0.001)$, with an intercept not different from zero and a slope not different from unity. The proportion of deviation points lying within the range -0.4 to $0.4 \mathrm{~kg} \cdot \mathrm{d}^{-1}$ was $90.1 \%$. The regression equation between observed and predicted ADG was: $Y_{\text {OBS }}=1.07 X_{\text {CNCPS }}-0.05\left(R^{2}=0.92 ; P<0.001\right)$, with an intercept not different from zero and a slope not different from unity. About $78.9 \%$ of points fell within the range -0.1 to $0.1 \mathrm{~kg} / \mathrm{d}$ for these cattle. Model-predicted faecal $\mathrm{N}$ excretion for the cattle breeds was close to the observed values. The regression equation between observed and predicted faecal $\mathrm{N}$ excretion was: $Y_{\text {OBS }}=1.04 X_{\text {CNCPS }}-1.48\left(R^{2}=0.94 ; P<0.001\right)$, with an intercept not different from zero and a slope not different from unity. About $73.3 \%$ of the points fell within -4 and $4 \mathrm{~g}$ per day. These results show that the CNCPSv6 model using actual feed fractions can give good predictions of DMI, ADG and faecal N excretion with different beef cattle breeds in China.
\end{abstract}

\section{Introduction}

Feed is the highest cost input in beef cattle production. Poor estimation of nutrient supply and animal requirements leads to high waste production and environmental pollution. Livestock farm activities have been described as contributors to $\mathrm{N}$ environmental pollution, and cattle have the largest share in manure $\mathrm{N}$ production (Oenema, 2006). There are about sixty-nine breeds of yellow cattle and thirteen imported cattle breeds making up the more than 100 million head of beef cattle in China (Zheng et al., 1986; Li et al., 2009). The local breeds usually have some advantage such as roughage tolerance, high stress resistance, low maintenance requirements, and early puberty, however, their growth performance and dressing percentage are lower (Liu et al., 2006). To improve growth performance and meat 
quality, China has imported some high-producing cattle breeds such as Limousin and Simmental from other countries.

Given our limited ability to measure the dry matter intake (DMI), average daily gain (ADG) and faecal $\mathrm{N}$ excretion of these cattle, the application of a nutritional model that can accurately estimate nutrient supply, animal requirements, and manure excretion in diverse production settings would be ideal. The Cornell Net Carbohydrate and Protein System (CNCPS) is a mathematical model to evaluate diet, animal performance and nutrient excretion that was developed from basic principles of rumen function, microbial growth, feed digestion and passage, and animal physiology over wide ranges of cattle, feed, management and environmental conditions (Fox et al., 1992, 2004). It has been used as a farm management tool to optimize use of farmspecific feeds, decrease the need for purchased supplements, optimize herd size, predict the manure produced that will have to be managed, and to improve the annual return over feed costs (Fox et al., 2004; Tylutki et al., 2004).

Nonetheless, many animal trials for model evaluation and refinement under Chinese feeding systems are necessary before its application can be recommended. Zhao et al. (2008) and Du et al. (2010) reported that it was acceptable to predict DMI and ADG of Chinese local beef cattle using the CNCPSv5 model. No carbohydrate and protein fractions based on the CNCPS model of feeds were actually determined in their reports, however. Also, little information is available to evaluate the CNCPSv6 in predicting faecal $\mathrm{N}$ excretion of different beef cattle breeds in China.

The objective of the present study was to evaluate the CNCPSv6 using actual carbohydrate and protein fractions of feeds in predicting DMI, ADG and faecal $\mathrm{N}$ excretion of local and imported cattle fed in China.

\section{Material and methods}

Data about animals, environment, management and feed intakes was collected and fit into the Cornell Net Carbohydrate and Protein System Version 6.1.26 (CNCPSv6) and the predicted outcomes were compared with the feeding results. The experiment was conducted at the China Agricultural University Beef Cattle Practical Education Base located in Daxing District, Beijing. All bulls were selected from different provinces of China and de-wormed before the feeding trials started.

\section{Experimental design}

Fifteen bulls of the Limousin (LIM), Simmental (SIM), Qinchuan (QC) and thirteen bulls of the Luxi (LX), Jinnan (JN) breeds were used in the current study. At the beginning of the trial, their body weights were $387.8 \pm 56.4 \mathrm{~kg}, 287.8 \pm 44.9 \mathrm{~kg}$, $236.3 \pm 21.7 \mathrm{~kg}, 241.5 \pm 32.8 \mathrm{~kg}$ and $246.7 \pm 43.1$ $\mathrm{kg}$ at the age of about 15 months for breeds LIM, SIM, LX, JN and QC, respectively. All of the bulls received the same finishing diets and management after 12 days adaptation from March 2009. The finishing period diet consisted of (\% DM): maize 44 , cotton seed meal 3 , soyabean pomace 8.8 , brewers dried grain 11 , maize stalk silage 30 , limestone 0.56 , dicalcium phosphate 0.14 , sodium bicarbonate 0.7 , salt 0.3 and compound premix 1.5. All bulls were housed individually in tie stalls and accessed the same total mixed ration ad libitum during the 105-day fattening period. Fresh water was available to animals by automatic drinkers.

\section{Sampling and analytical procedure}

The diets provided to each animal were weighed and recorded before the morning feeding and the feed refusals were collected and weighed on the next day before the morning feeding. Both feed and refusals samples were collected daily and brought to the laboratory for DM determination. Feed samples were determined following the CNCPSv6 recommended procedures. Total crude protein $(\mathrm{CP})$ was determined by the combustion method (AOAC, 1990) using a nitrogen analyzer (Model Rapid $\mathrm{N}$ III, Elementar, Germany). Neutral detergent fibre (NDF), acid detergent fibre (ADF), neutral detergent insoluble CP (NDIP) and acid detergent insoluble CP (ADIP) were determined using the methods by Van Soest et al. (1991). The non-protein nitrogen (NPN) and soluble CP (SCP) of the feeds were determined using the method of Licitra et al. (1996). Starch was determined by the method of Xiong et al. (1990). Volatile fatty acids (VFA) and lactic acid were determined (Richard and David, 1987 ) by gas chromatography (SP-3420, BeifenRuili, China). Organic acids were analysed (Russell and Van Soest, 1984) by high performance liquid chromatography (1100, Agilent, USA). Sugars were measured using ethanol/water extractions (Hall, 2003). Soluble fibres were calculated using the CNCPS carbohydrate fraction equation (Lanzas et al., 2007). Feed nutrient composition (Table 1) and feed carbohydrate and protein fractions (Table 2) were calculated according to the equations in Tylutki et al. (2008). 
Table 1. Nutrient composition of feeds offered to the cattle during finishing period

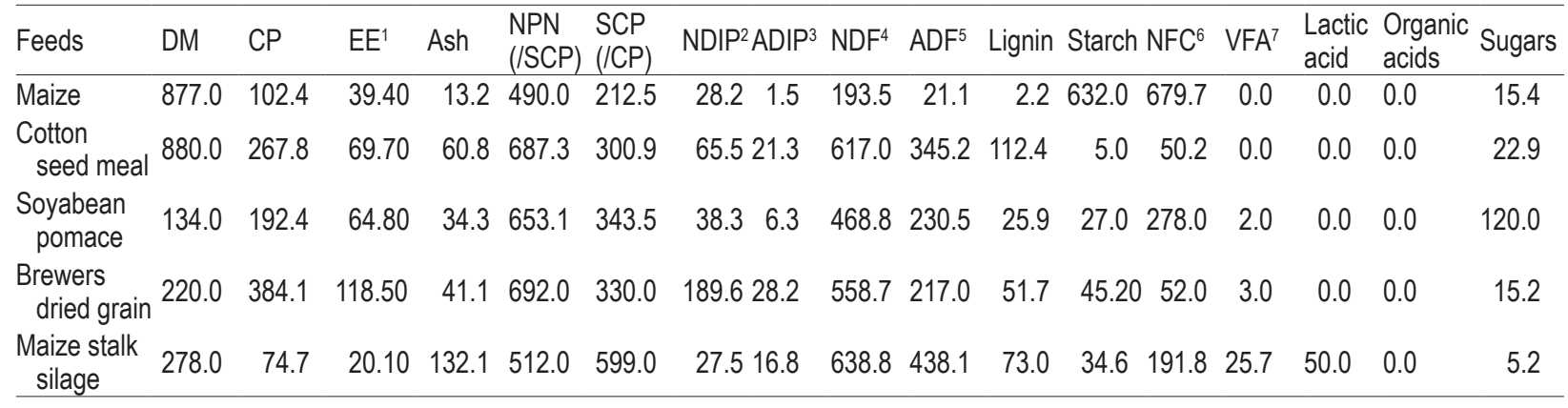

the unit for dry matter (DM) is $\mathrm{g} \cdot \mathrm{kg}^{-1}$ sample, for non-protein nitrogen (NPN) is $\mathrm{g} \cdot \mathrm{kg}^{-1}$ soluble crude protein (SCP), for SCP is $\mathrm{g} \cdot \mathrm{kg}^{-1} \mathrm{Crude}$ protein (CP) and for others is $\mathrm{g} \cdot \mathrm{kg}^{-1} \mathrm{DM} ;{ }^{1}$ ether extract; ${ }^{2}$ neutral detergent insoluble $\mathrm{CP} ;{ }^{3}$ acid detergent insoluble $\mathrm{CP} ;{ }^{4}$ neutral detergent fibre; ${ }^{5}$ acid detergent fibre; ${ }^{6}$ non-fibre carbohydrates; ${ }^{7}$ volatile fatty acids

Table 2. Carbohydrate and protein fractions of finishing period feeds

\begin{tabular}{|c|c|c|c|c|c|c|c|c|c|c|c|c|c|}
\hline \multirow{2}{*}{ Feeds } & \multicolumn{13}{|c|}{ Fractions $^{1}, \mathrm{~g} \cdot \mathrm{kg}^{-1} \mathrm{DM}$} \\
\hline & CA1 & CA2 & CA3 & CA4 & CB1 & CB2 & CB3 & $\mathrm{CC}$ & PA & PB1 & PB2 & PB3 & PC \\
\hline Maize & 0.0 & 0.0 & 0.0 & 15.4 & 632.0 & 160.0 & 32.3 & 0.5 & 10.7 & 11.1 & 52.4 & 26.7 & 1.5 \\
\hline Cotton seed meal & 0.0 & 0.0 & 0.0 & 22.9 & 5.0 & 281.7 & 22.3 & 27.0 & 55.4 & 25.2 & 121.7 & 44.2 & 21.3 \\
\hline Soyabean pomace & 2.0 & 0.0 & 0.0 & 20.0 & 27.0 & 368.3 & 129.0 & 6.2 & 43.2 & 22.9 & 88.0 & 32.0 & 6.3 \\
\hline Brewers dried grain & 3.0 & 0.0 & 0.0 & 15.2 & 52.0 & 245.0 & 17.0 & 12.4 & 87.7 & 39.0 & 67.8 & 161.4 & 28.2 \\
\hline Maize stalk silage & 25.7 & 50.0 & 0.0 & 5.2 & 34.6 & 436.1 & 46.3 & 17.5 & 22.9 & 21.8 & 2.5 & 10.7 & 16.8 \\
\hline
\end{tabular}

${ }^{1} \mathrm{CA} 1$ = acetic + propionic + butyric + isobutyric; $\mathrm{CA} 2$ - lactic acid; CA3 - other organic acids; $\mathrm{CA} 4$ - sugars; $\mathrm{CB} 1$ - starch; CB2 = NFC - CA1 $\mathrm{CA} 2-\mathrm{CA} 3-\mathrm{CA} 4-\mathrm{CB} 1 ; \mathrm{CB} 3=(\mathrm{NDF}-(\mathrm{NDIP} \times \mathrm{CP})) / 1000-\mathrm{CC} ; \mathrm{CC}=$ lignin $\times 2.4 ; \mathrm{PA}-$ non-protein nitrogen $(\mathrm{NPN}) ; \mathrm{PB} 1=$ soluble CP $(\mathrm{SCP})$ - NPN; PB2 = CP - SCP - neutral detergent insoluble CP (NDIP); PB3 = NDIP - acid detergent insoluble CP (ADIP); PC=ADIP

Table 3. Description of the model inputs common to all the animals, within each trial group, used for evaluation of the dry matter intake, average daily gain and faecal $\mathrm{N}$ excretion predictions by the CNCPS model

\begin{tabular}{|c|c|c|c|c|c|}
\hline \multirow{2}{*}{ Item } & \multicolumn{5}{|l|}{ Breed } \\
\hline & Breed 1 & Breed 2 & Breed 3 & Breed 4 & Breed 5 \\
\hline \multicolumn{6}{|l|}{ Farm } \\
\hline $\begin{array}{l}\text { name } \\
\text { farm type }\end{array}$ & $\begin{array}{l}\text { Jinwei Furen } \\
\text { beef }\end{array}$ & $\begin{array}{l}\text { Jinwei Furen } \\
\text { beef }\end{array}$ & $\begin{array}{l}\text { Jinwei Furen } \\
\text { beef }\end{array}$ & $\begin{array}{l}\text { Jinwei Furen } \\
\text { beef }\end{array}$ & $\begin{array}{l}\text { Jinwei Furen } \\
\text { beef }\end{array}$ \\
\hline \multicolumn{6}{|l|}{ Location } \\
\hline location type & tie-stall & tie-stall & tie-stall & tie-stall & tie-stall \\
\hline animal type & growing & growing & growing & growing & growing \\
\hline temperature, ${ }^{\circ} \mathrm{C}$ & 30 & 30 & 30 & 30 & 30 \\
\hline previous temperature, ${ }^{\circ} \mathrm{C}$ & 10 & 10 & 10 & 10 & 10 \\
\hline relative humidity, $\%$ & 45 & 45 & 45 & 45 & 45 \\
\hline previous relative humidity, $\%$ & 60 & 60 & 60 & 60 & 60 \\
\hline wind speed, $\mathrm{km} \cdot \mathrm{h}^{-1}$ & 11 & 11 & 11 & 11 & 11 \\
\hline previous wind speed, $\mathrm{kg} \cdot \mathrm{h}^{-1}$ & 15 & 15 & 15 & 15 & 15 \\
\hline \multicolumn{6}{|l|}{ Environment } \\
\hline storm exposure & false & false & false & false & false \\
\hline minimum night temperature, ${ }^{\circ} \mathrm{C}$ & -5 & -5 & -5 & -5 & -5 \\
\hline hours in standing & 12 & 12 & 12 & 12 & 12 \\
\hline mud depth, cm & 2 & 2 & 2 & 2 & 2 \\
\hline \multicolumn{6}{|l|}{ Cattle inputs } \\
\hline number of animals & 15 & 15 & 13 & 15 & 13 \\
\hline days in circle & 105 & 105 & 105 & 105 & 105 \\
\hline body condition score (BCS) & 4 & 4 & 3 & 3 & 3 \\
\hline breed type & Limousin & Simmental & Luxi & Qinchuan & Jinnan \\
\hline hair depth & 0.6 & 0.6 & 0.6 & 0.6 & 0.6 \\
\hline coat condition & mud on legs & mud on legs & mud on legs & mud on legs & mud on legs \\
\hline panting & none & none & none & none & none \\
\hline final shrunk body weight, $\mathrm{kg}$ & 550 & 410 & 310 & 320 & 330 \\
\hline final body fat, $\%$ & 25 & 25 & 25 & 25 & 25 \\
\hline
\end{tabular}


Table 4. Description of the model inputs used for the $\mathrm{DMI}^{1}, \mathrm{ADG}^{2}$ and faecal $\mathrm{N}$ excretion predictions by the CNCPS

\begin{tabular}{|c|c|c|c|c|c|}
\hline & \multicolumn{5}{|l|}{ Breed $^{3}$} \\
\hline & $\overline{\text { LIM }}$ & SIM & LX & QC & $\mathrm{JN}$ \\
\hline No. in treatments & 15 & 15 & 13 & 15 & 13 \\
\hline Initial body weight, $\mathrm{kg}$ & $397.8 \pm 56.4$ & $297.8 \pm 44.9$ & $245.3 \pm 21.7$ & $255.7 \pm 43.1$ & $250.5 \pm 32.8$ \\
\hline Final body weight, $\mathrm{kg}$ & $560.3 \pm 48.5$ & $422.0 \pm 52.7$ & $329.9 \pm 20.8$ & $334.2 \pm 49.0$ & $338.8 \pm 35.3$ \\
\hline $\mathrm{ADG}, \mathrm{kg} \cdot \mathrm{d}^{-1}$ & $1.50 \pm 0.22$ & $1.20 \pm 0.20$ & $0.82 \pm 0.11$ & $0.78 \pm 0.14$ & $0.82 \pm 0.22$ \\
\hline
\end{tabular}

${ }^{1} \mathrm{DMI}$ - dry matter intake; ${ }^{2} \mathrm{ADG}$ - average daily gain; ${ }^{3} \mathrm{LIM}$ - Limousin, SIM - Simmental, LX - Luxi, QC - Qinchuan, JN - Jinnan

\section{Measurement of animal performance}

Before the morning feeding, the animals were weighed for the last 2 consecutive days at the end of adaptation and every 35 days during the experimental fattening period. ADG was calculated dividing the difference between final and initial liveweight by the number of days of the experiment. The final shrunk body weight (SBW) was assumed as $550 \mathrm{~kg}$, $410 \mathrm{~kg}, 310 \mathrm{~kg}, 320 \mathrm{~kg}$ and $330 \mathrm{~kg}$ for LIM, SIM, LX, QC and JN, respectively, and the expected body fat composition was set at $250 \mathrm{~g} \cdot \mathrm{kg}^{-1}$ (Table 3 ), which should represent an average level of body weight and target body fat in the current beef finishing system in China (Zhao et al., 2008).

\section{Faeces collection}

For the last $5 \mathrm{~d}$ of the finishing period, six animals from each breed were randomly selected for total faeces collection. Faeces were collected in large buckets placed in the gutter behind the cattle. Faeces were pre-acidified with $10 \% \mathrm{H}_{2} \mathrm{SO}_{4}$ to adjust the $\mathrm{pH}$ of samples to below 3 to minimize ammonia losses. Daily faecal composites were mixed and frozen at $-4^{\circ} \mathrm{C}$. The dry matter content of faeces was determined by drying at $105^{\circ} \mathrm{C}$ until constant weight. Nitrogen of faeces was determined by the combustion method (AOAC, 1990) using a nitrogen analyzer (Model Rapid N III, Elementar, Germany).

\section{Model inputs and outputs}

All data and observed information were entered into the model. Model predictions, including DMI and ADG, were generated for each bull using its individual body weight records over the period of 105 days in this experiment. Environmental temperature and relative humidity were recorded twice per day at 7.00 and 16.00 using a hygrothermograph (EAWSD, HUARUI Corporation, Beijing). The most important variables, including feed composition and fractions (Tables 1 and 2), location type, animal description, environmental parameters (Tables 3 and 4) were used in the models for the evaluation of DMI, ADG and faecal N loss.

The equations used for computing feed energy by CNCPS can be found in the model docu- mentation (Fox et al., 2004). The dietary content of metabolizable energy was $2.66 \mathrm{Mcal} \cdot \mathrm{kg}^{-1} \mathrm{DM}$, net energy for maintenance was $1.75 \mathrm{Mcal} \cdot \mathrm{kg}^{-1}$ $\mathrm{DM}$, and net energy for growth was 1.13 Mcal - $\mathrm{kg}^{-1} \mathrm{DM}$ calculated by the computer model. The equations used by CNCPSv6 can be found in the model documentation (Tylutki et al., 2008). ADG values were predicted based on ingested metabolizable energy allowance automatically calculated by the computer model.

\section{Statistical evaluation criteria}

As described in Molina et al. (2004) and Zhao et al. (2008), model predictions were evaluated for accuracy (the closeness to which a prediction approaches the experimentally determined value) and precision (repeatability of predictions) by comparing predicted to observed data. The mean bias, the mean square prediction error (MSPE) (Tedeschi, 2006), and the statistical measures of model performance (Mitchell and Sheehy, 1997) were calculated as described by Tedeschi et al. (2000).

Model-predicted performance was also evaluated using analysis of regression between the observed (Y-variate) and the model-predicted (Xvariate) values, as described by Mayer and Butler (1993). The reported $\mathrm{R}^{2}$ and mean square error (MSE) were obtained from the linear regression.

Another approach to evaluating model adequacy included determination of the proportion of deviation points (CNCPS model-predicted minus observed) that lie within acceptable limits (Mitchell and Sheehy, 1997). Limits of -0.4 to $0.4 \mathrm{~kg} \cdot \mathrm{day}^{-1}$ for DMI comparisons, -0.1 to $0.1 \mathrm{~kg} \cdot$ day $^{-1}$ for ADG comparisons, and -4 to $4 \mathrm{~g} \cdot$ day $^{-1}$ for faecal $\mathrm{N}$ excretion were established. This range approximately represents the values delimiting the $95 \%$ confidence interval for DMI and ADG means observed in the trials (Molina et al., 2004).

All statistical analyses were performed using SAS Version 8.02 (1999). Estimates of regression values were obtained using the statement of PROC REG, and the statistical comparison between observed and predicted values was performed using the pair-t test. 


\section{Results}

\section{Evaluation of model-predicted dry matter intake}

The model-predicted DMI for the cattle breeds were extremely close to the observed values, showing low mean biases and low root mean square prediction error (RMSPE) values (Table 5) obtained from these data, which reflects the high accuracy of the model predictions for most of the breeds. Nevertheless, SIM treatment still had the highest mean biases of $-0.17 \mathrm{~kg} \mathrm{DM} \cdot$ day $^{-1}$ and RMSPE of 0.35 .
The results of observed versus CNCPS modelpredicted DMI for overall breed treatments are shown in Figure 1. From distribution of points along the unity line, no systematic prediction error was observed in this trial (Figure 1A). For variation of CNCPS predicted minus observed DMI, the pro portion of deviation points lying within the range -0.4 to $0.4 \mathrm{~kg} \cdot$ day $^{-1}$ was extremely high $(90.1 \%)$ (Figure 1B).

Estimates of the regression parameters between the observed versus model-predicted DMI are shown in Table 6. The intercept and slope values were

Table 5. Comparison between observed $\mathrm{DMI}^{1}, \mathrm{ADG}^{2}$ and faecal $\mathrm{N}$ excretion and CNCPS-predicted dry matter intake, average daily gain and faecal $N$ excretion

\begin{tabular}{|c|c|c|c|c|c|}
\hline & \multicolumn{5}{|l|}{ Breed $^{3}$} \\
\hline & LIM & SIM & $L X$ & QC & $\mathrm{JN}$ \\
\hline \multicolumn{6}{|l|}{ Dry matter intake } \\
\hline no. in treatments & 15 & 15 & 13 & 15 & 13 \\
\hline CNCPS-predicted DMI, kg & $8.60 \pm 0.55$ & $7.34 \pm 0.59$ & $6.08 \pm 0.34$ & $6.05 \pm 0.45$ & $6.25 \pm 0.46$ \\
\hline observed DMI, kg & $8.47 \pm 0.40$ & $7.51 \pm 0.45$ & $6.12 \pm 0.47$ & $6.02 \pm 0.51$ & $6.30 \pm 0.51$ \\
\hline mean bias, $\mathrm{kg} \mathrm{DM}^{1}$ & 0.13 & -0.17 & -0.04 & 0.03 & -0.05 \\
\hline RMSPE $^{2}$ & 0.22 & 0.35 & 0.29 & 0.27 & 0.26 \\
\hline \multicolumn{6}{|l|}{ Average daily intake } \\
\hline no. in treatments & 15 & 15 & 13 & 15 & 13 \\
\hline CNCPS-predicted ADG & $1.48 \pm 0.20$ & $1.09 \pm 0.12$ & $0.85 \pm 0.07$ & $0.77 \pm 0.09$ & $0.84 \pm 0.19$ \\
\hline observed ADG & $1.50 \pm 0.22$ & $1.20 \pm 0.20$ & $0.82 \pm 0.11$ & $0.78 \pm 0.14$ & $0.82 \pm 0.22$ \\
\hline mean bias ${ }^{1}$ & -0.02 & -0.11 & 0.03 & -0.01 & 0.02 \\
\hline $\mathrm{RMSPE}^{2}$ & 0.10 & 0.16 & 0.06 & 0.08 & 0.05 \\
\hline \multicolumn{6}{|l|}{ Faecal $\mathrm{N}$-excretion } \\
\hline no. in treatments & 6 & 6 & 6 & 6 & 6 \\
\hline CNCPS-predicted faecal N & $99.08 \pm 16.95$ & $68.67 \pm 4.63$ & $60.83+4.26$ & $58.00 \pm 5.21$ & $63.67 \pm 3.67$ \\
\hline observed faecal N & $94.50 \pm 15.71$ & $70.67 \pm 6.91$ & $59.67 \pm 4.41$ & $56.13 \pm 4.72$ & $62.33 \pm 1.96$ \\
\hline mean bias ${ }^{1}$ & 4.58 & -2.00 & 1.16 & 1.87 & 1.34 \\
\hline RMSPE $^{2}$ & 5.77 & 4.91 & 3.60 & 4.42 & 4.70 \\
\hline
\end{tabular}

${ }^{1}$ mean bias is the average of CNCPS - predicted minus observed; ${ }^{2}$ RMSPE - root mean square prediction error; ${ }^{3}$ - breed see Table 4
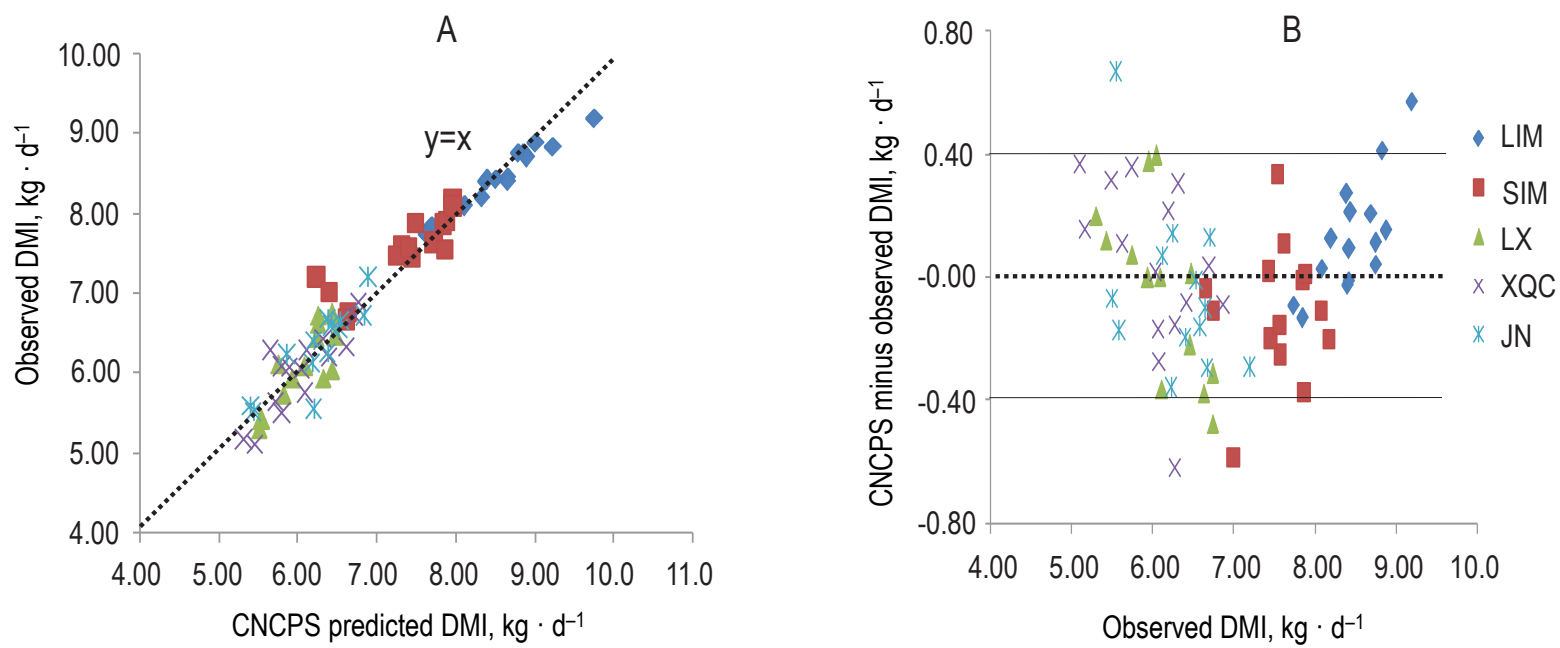

Figure 1. Prediction of dry matter intake (DMI) by Cornell Net Carbohydrate and Protein System (CNCPS).A. Relationship between observed DMI and CNCPS-predicted DMl $\left(\mathrm{kg} \cdot \mathrm{d}^{-1}\right)$ of five breeds. Data are from five cattle breed treatments, number $=71$. B. Variation of CNCPS-predicted minus observed DMI vs observed DMI demonstrated that about $90.1 \%$ of the points are within the range -0.4 to $0.4 \mathrm{~kg} \cdot \mathrm{d}^{-1}$ 
Table 6. Regression of observed upon CNCPS-predicted dry matter intake $\left(\mathrm{kg} \cdot \mathrm{d}^{-1}\right)$, of observed upon CNCPS-predicted daily weight gain $\left(\mathrm{kg} \cdot \mathrm{d}^{-1}\right)$ and of observed upon CNCPS-predicted faecal N excretion $\left(g \cdot d^{-1}\right)$

\begin{tabular}{lllll}
\hline Item & Intercept & Slope & $\mathrm{R}^{2}$ & $\mathrm{RMSE}^{1}$ \\
\hline
\end{tabular}

Dry matter intake, $\mathrm{kg} \cdot$ day $^{-1} \quad 0.48 \pm 0.200 .93 \pm 0.03 \quad 0.94 \quad 0.27$

Daily weight gain, $\mathrm{kg} \cdot$ day $^{-1}-0.05 \pm 0.031 .07 \pm 0.04 \quad 0.920 .09$

Faecal N excretion, g day $^{-1}-1.48 \pm 2.351 .04 \pm 0.040 .944 .10$

${ }^{1} \mathrm{RMSE}$, root mean square error

not statistically different from zero and $1(P>0.05)$ for these cattle. The regression equation between observed ( $\mathrm{Y}$ variate) and predicted $(\mathrm{X}$ variate) DMI was: $\mathrm{Y}_{\mathrm{OBS}}=0.93 \mathrm{X}_{\mathrm{CNCPS}}+0.48\left(\mathrm{R}^{2}=0.94\right.$; $P<0.001)$.

\section{Evaluation of model-predicted average daily gain}

A comparison between observed and CNCPS model-predicted ADG for all the five breeds is shown in Table 5. Mean biases between model-predicted and observed ADG in most of these treatments were very low, suggesting fairly accurate predictions of CNCPS. While the CNCPS-predicted ADG for SIM was not as accurate as the others, with the highest mean bias of $-0.11 \mathrm{~kg}$ per day and RMSPE of 0.16 .

The relationships between observed and CNCPSv6 predicted ADG for the five breeds are illustrated in Figure 2A. The plot of observed versus CNCPS-predicted ADG for these cattle had an even distribution of points along the unity line and did not have any systematic prediction error. The proportion of deviation points lying within -0.1 and $0.1 \mathrm{~kg}$ per day was high (78.9\%) for these cattle (Figure 2B).
Estimates of regression parameters about ADG between observation and model prediction are shown in Table 6. The regression equation in this trial between observed ( $\mathrm{Y}$ variate) and predicted (X variate) $\mathrm{ADG}$ was: $\mathrm{Y}_{\mathrm{OBS}}=1.07 \mathrm{X}_{\mathrm{CNCPS}}-0.05$ $\left(\mathrm{R}^{2}=0.92 ; P<0.001\right)$.

\section{Evaluation of model-predicted faecal $N$ excretion}

Model-predicted faecal $\mathrm{N}$ excretion values for the cattle breed treatments were close to those observed, showing relatively low mean biases and low RMSPE values (Table 5). Nevertheless, most of the treatments had positive values of mean biases, indicating that faecal $\mathrm{N}$ excretion was over-predicted by the CNCPSv6 model in the present study.

The relationships between observed and CNCPSv6-predicted faecal $\mathrm{N}$ excretion for the five breeds are illustrated in Figure 3A. The plot of observed versus CNCPS-predicted faecal $\mathrm{N}$ excretion for these cattle had an even distribution of points along the unity line and did not show systematic prediction error. The proportion of deviation points lying within -4 and $4 \mathrm{~kg}$ per day was $73.3 \%$ for these cattle (Figure 3B).

Estimates of regression parameters about faecal N excretion between observation and CNCPSprediction are shown in Table 6. The regression equation in this trial between observed ( $\mathrm{Y}$ variate) and predicted ( $\mathrm{X}$ variate) faecal $\mathrm{N}$ excretion was: $\mathrm{Y}_{\mathrm{OBS}}=1.04 \mathrm{X}_{\mathrm{CNCPS}}-1.48\left(\mathrm{R}^{2}=0.94 ; P<0.001\right)$.
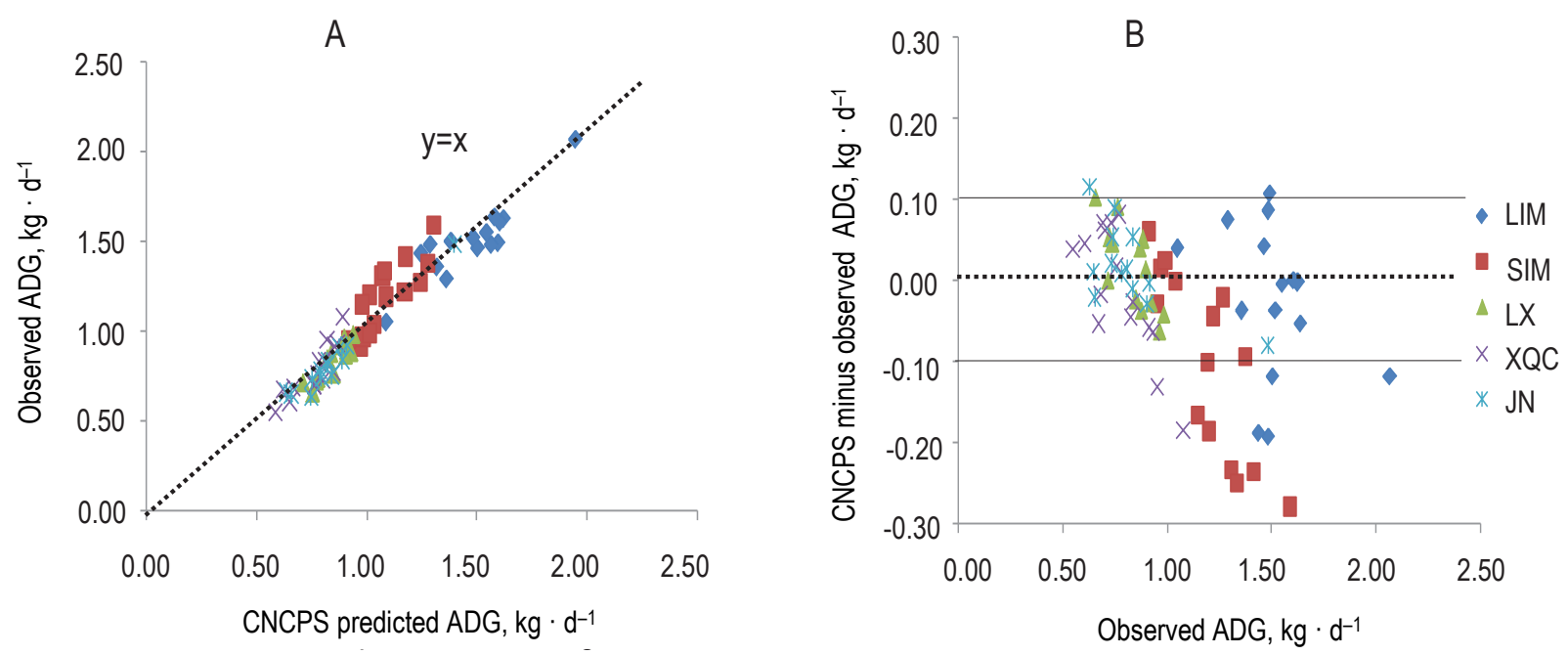

Figure 2. Prediction of average daily gain (ADG) by Cornell Net Carbohydrate and Protein System (CNCPS). A. Relationship between observed ADG and CNCPS-predicted ADG $\left(\mathrm{kg} \cdot \mathrm{d}^{-1}\right)$ of five breeds. Data are from five cattle breed treatments, number $=71$. B. Variation of CNCPS-predicted minus observed $A D G$ vs. observed $A D G$ demonstrated that about $78.9 \%$ of the points are within the range -0.1 to $0.1 \mathrm{~kg} \cdot \mathrm{d}^{-1}$ 

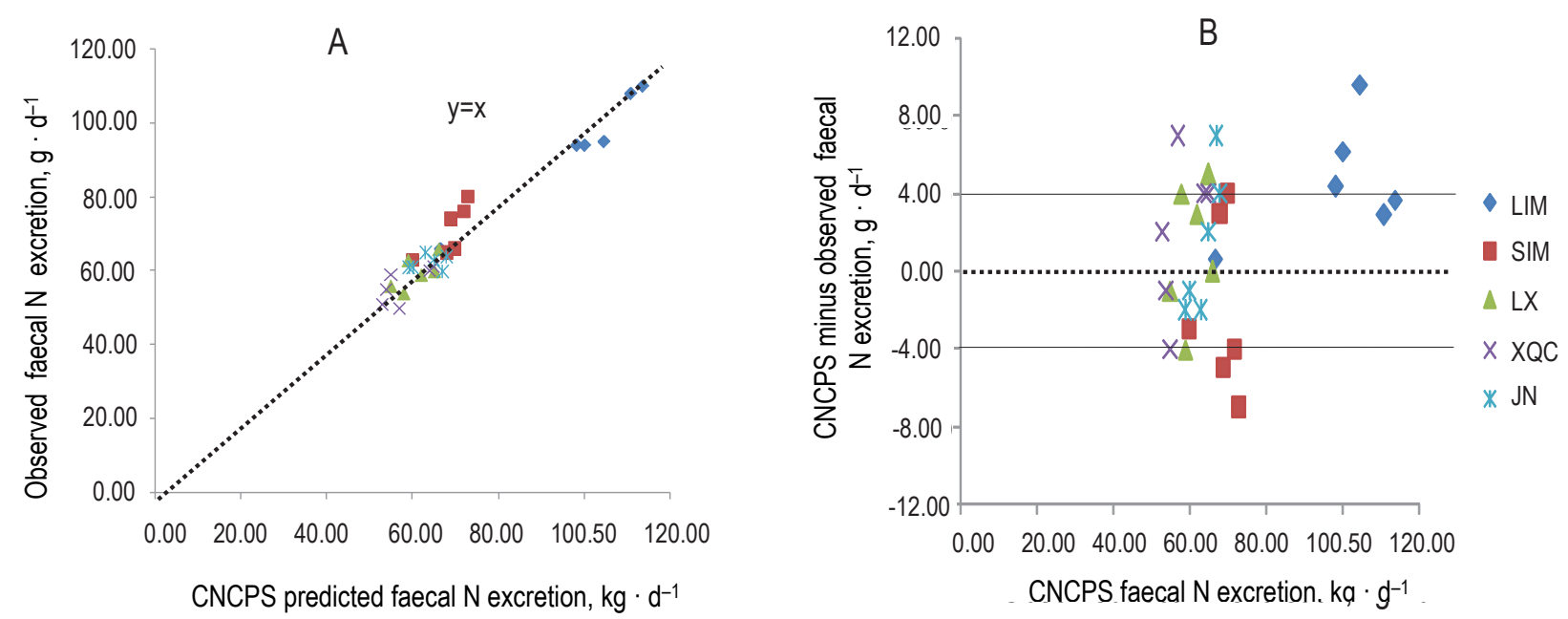

Figure 3. Prediction of faecal N excretion by Cornell Net Carbohydrate and Protein System (CNCPS). A. Relationship between observed faecal $\mathrm{N}$ excretion and CNCPS-predicted faecal $\mathrm{N}$ excretion $\left(\mathrm{g} \cdot \mathrm{d}^{-1}\right)$ of five breeds. Data are from five cattle breed treatments, number $=30$. B. Variation of CNCPS-predicted minus observed faecal $\mathrm{N}$ excretion vs. observed faecal $\mathrm{N}$ excretion demonstrated that about $73.3 \%$ of the points are within the range -4 to $4 \mathrm{~g} \cdot \mathrm{d}^{-1}$

\section{Discussion}

\section{Evaluation of the CNCPS-predicted dry matter intake and average daily gain}

Accurate and precise predictions of DMI and ADG are vitally important in beef cattle production today. The CNCPS is a mathematical model for evaluating diet and animal performance. Tylutki et al. (2008) reported that CNCPSv6, which represents a re-engineering and updating of CNCPS version 5 improved its ability to formulate and evaluate a feeding programme for a herd of dairy cattle with greater accuracy and efficiency. In this study, we evaluated the coincidence of DMI and ADG values predicted by CNCPSv6 and observed in five breeds of growing bulls kept on typical feed resources in Northern China. The CNCPS-predicted DMI and ADG values were based on available information, such as animal source, weather conditions, dietary nutrient density, feed available energy level, and others (Zhao et al., 2008). The actual DMI and ADG values of each animal were measured and calculated individually, and then pooled to be expressed as an average per breed (Zhao et al., 2008).

The RMSPE and mean biases indicated the CNCPSv6 model can predict DMI and ADG of Chinese beef cattle. According to the criteria described by Zhao et al. (2008), ideal linear regression equations for comparing the predicted and observed DMI and ADG need to meet three criteria: 1 . high $\mathrm{R}^{2}$ value (>0.75 as a reference), 2. intercept close to (not different from) zero, and 3. slope close to 1 . In this study, the $\mathrm{R}^{2}$ values of regressions between observed and predicted DMI and ADG were high
(0.94 and 0.92, respectively) and the intercept and slope were not statistically different from 0 or 1 , respectively. When compared with the results reported by Zhao et al. (2008) and Du et al. (2010), the regression results between observed and predicted DMI and ADG were better in this study.

For growing cattle, prediction of dry matter intake and daily gain is dependent on accurate prediction of NE available for maintenance (NEm) and gain (NEg), which in turn depends on accurate assessment of maintenance requirements and feed energy values (Fox et al., 1992). DMI and ADG predictions with CNCPSv6 in this study were directly dependent on the amount of NEm and retained energy (RE) of the diet. The NEm and RE of the daily ration in this study were predicted based on actual feed chemical analysis. In previous reports described by Zhao et al. (2008) and Du et al. (2010), the feed fractions of diet used for model input were calculated based on the CNCPS feed library rather than actually determined. The use of tabulated feed data rather than actual laboratory determinations may have caused prediction errors (Zhao et al., 2008; Du et al., 2010). So the better results predicted by CNCPSv6 for DMI and ADG in the present study can be ascribed to the actual feed fractions used and re-engineering and updating objectives in the model.

\section{Evaluation of the CNCPS-predicted faecal $\mathbf{N}$ excretion}

Accurate and precise predictions of total $\mathrm{N}$ excretion are important for beef cattle producers to plan entire feeding and farm nutrient management. Due to conditional restrictions, however, 
urinary $\mathrm{N}$ excretion was not determined in the present study. According to the values of $\mathrm{R}^{2}$ and proportion of deviation points obtained from this data, it is implied that the CNCPSv6 model can be acceptable to predict faecal $\mathrm{N}$ excretion of Chinese cattle raised in Northern China. The positive values of mean bias, derived from most of these breeds, revealed, however, that faecal N excretion was over-predicted by the CNCPSv6 model in the present study. According to Fox et al. (2003, 2004), faecal $N$ loss is composed of bacterial faecal $\mathrm{N}$, faecal $\mathrm{N}$ from indigestible feed and metabolic faecal N (MFN). The current faecal $\mathrm{N}$ loss equation may result in 'double accounting', however. Some of the MFN and undigested feed ash is excreted as microbial mass, and therefore $\mathrm{N}$ excretion is over-predicted (Fox et al., 2004). So a mechanistic hindgut sub-model will be required to accurately predict the fermentative processes occurring in the large intestine, including the production and absorption of volatile fatty acids, the capture of $\mathrm{N}$ by hindgut bacteria, $\mathrm{N}$ recycling of urea and the absorption of ammonia from the lower tract (Fox et al., 2004).

Because of the conditional restrictions, just faecal $\mathrm{N}$ excretion was determined in the current study. In future, the route (faecal or urinary) and form (potentially volatilized to ammonia) of $\mathrm{N}$ excretion will be needed for further evaluating.

\section{Consideration of systematic adjustment of CNCPS model and establishment of feedstuffs database}

Although the predictions of dietary DMI, ADG and faecal $\mathrm{N}$ excretion of the Chinese local and imported beef cattle by the CNCPSv6 model were satisfactory and accurate, some adjustment factors should be considered. Though temperature factor (TEMP1), mud factors (MUD), body fat factors (BFAF), and revised carbohydrate fractionation were already specially considered in this study, adjustments for fibre digestion, microbial mass production from ruminally-degraded carbohydrate (Tedeschi et al., 2000), and beef breed factor (Zhao et al., 2008; Du et al., 2010), should also be included. The two imported cattle breeds have undergone graded crossing for many years in China, so the Limousin and Simmental cattle breeds were chosen as default breed input for LIM and SIM, respectively. As no data were available on Chinese local beef cattle breeds in the CNCPS system, Gelbvieh was chosen as the default breed for local breeds because of their common traits such as birth weight, yellow colour, and medium to late maturity. The average daily gain and the mature body weight between Gelbvieh and Chinese local breeds were not the same, however. These may have affected the predictions of DMI, ADG and faecal N excretion. More research is still needed to create appropriate breed adjustment factors for the future prediction of Chinese crossbred and local beef cattle.

The accuracy of prediction of nutrient requirements and performance under specific conditions depends on the accuracy of description of feedstuff composition and DMI (Fox et al., 2003). Lanzas et al. (2007) reported that the expanded carbohydrate scheme provides a more biologically correct and appropriate feed description that more closely relates to rumen fermentation characteristics to account for variation in changes in silage quality and diet NFC composition. In the present study, the feed carbohydrate and protein fractions were analysed and better predictions were obtained. The use of the CNCPS model for prediction of performance and nutrient excretion in China is just at the primary stage, however. The lack of basic feed information fitting the CNCPS has restricted the application of the model in practice (Zhao et al., 2008; Du et al., 2010). In this study, only five feedstuffs were analysed using CNCPS model methods. There are, however, many feed resources, including abundant by-products in China, so it is vitally important to create a useful database with indices required by the CNCPS to use this model.

\section{Conclusions}

The results indicated that the dry matter intake, average daily gain and faecal $\mathrm{N}$ excretion predictions of the CNCPSv6 model are satisfactory and accurate for Chinese local and imported cattle breeds based on actual carbohydrate and protein fractions in this model. Further studies including breed adjustment factors are warranted to give systematic adjustment of the model. It is also imperative to build feed databases for the potential application of the CNCPS model in China.

\section{Acknowledgements}

This research was financed by the China National Supporting Project (No. 2006BAD12B02) and the Earmarked Fund for Modern Agro-Industry Technology Research System (Beef Cattle and Yaks, CARS-38). 


\section{References}

AOAC, 1990. Association of Official Analytical Chemists, Official Methods of Analysis. $16^{\text {th }}$ Edition. Gaithersburg, MD

Du J.P., Liang Y., Xin H.S., Xue F., Zhao J.S., Ren L.P., Meng Q.X., 2010. Evaluation of dry matter intake and average daily gain predicted by the Cornell Net Carbohydrate and Protein System in crossbred growing bulls kept in a traditionally confined feeding system in China. Asian-Austr. J. Anim. Sci. 23, 1445-1454

Fox D.G., Sniffen C.J., O'Comor J.D., Russell J.B., Van Soest P.J., 1992. A Net Carbohydrate and Protein System for evaluating cattle diets: III. cattle requirements and diet adequacy. J. Anim. Sci. 70, 3578-3596

Fox D.G., Tedeschi L.O., Tylutki T.P., Russell J.B., Van Amburgh M.E., Chase L.E., Pell A.N., Overton T.R., 2004. The Cornell Net Carbohydrate and Protein System model for evaluating herd nutrition and nutrient excretion. Anim. Feed Sci. Tech. 112, 29-78

Fox D.G., Tylutki T.P., Tedeschi L.O., Van Amburgh M.E., Chase L.E., Pell A.N., Overton T R., Russell J.B., 2003. The net carbohydrate and protein system for evaluating herd nutrition and nutrient excretion. CNCPS version 5.0, Model Documentation. Ithaca, NY (USA)

Hall M.B., 2003. Challenges with nonfiber carbohydrate methods. J. Anim. Sci. 81, 3226-3232

Lanzas C., Sniffen C.J., Seo S., Tedeschi L.O., Fox D.G., 2007. A revised CNCPS feed carbohydrate fractionation scheme for formulating rations for ruminants. Anim. Feed Sci. Tech. 136, 167-190

Li X.Q., Wang H.M., Chen Y.Y., 2009. Several considerations on how to promote beef industry being healthy development in China. Chin. J. Anim. Sci. 45 (22), 43-46

Licitra G., Hernandez T.M., Van Soest P.J., 1996. Standardization of procedures for nitrogen fractionation of ruminant feeds. Anim. Feed Sci. Tech. 57, 347-358

Liu B., Chen H., Lan X.Y., Zhang Z.Q., Zhang R.F., 2006. Research on heterosis and growth performance in Qinchuan and its hybrids. Chin. J. Anim. Sci. 42 (15), 1-4

Mayer D.G., Butler D.G., 1993. Statistical validation. Ecol. Model. 68, 21-32

Mitchell P.L., Sheehy J.E., 1997. Comparison of predictions and observations to assess model performance: a method of empirical validation. In: M.J. Kropff, P.S. Teng, P.K. Aggarwal, J. Bouma, B.A. M. Bouman, J.W. Jones, H.H. Van Laar (Edi- tors). Applications of Systems Approaches at the Field Level. Kluwer Academic Publishers, Boston (USA), pp. 437-451

Molina D.O., Matamoros I., Almeida Z., Tedeschi L., Pell A.N., 2004. Evaluation of the dry matter intake predictions of the Cornell Net Carbohydrate and Protein System with Holstein and dualpurpose lactating cattle in the tropics. Anim. Feed Sci. Tech. $114,261-278$

Oenema O., 2006. Nitrogen budgets and losses in livestock systems. Int. Congr. 1293, 262-271

Richard J.F., David V.M., 1987. Determination of volatile fatty acids (C2-C5) and lactic acid in silage by gas chromatography. Analyst 112, 1213-1216

Russell J.B., Van Soest P.J., 1984. In vitro ruminal fermentation of organic acids common in forage. Appl. Environ. Microbiol. 47, 155-159

Tedeschi L.O., 2006. Assessment of the adequacy of mathematical models. Agr. Syst. 89, 225-247

Tedeschi L.O., Fox D.G., Russell J.B., 2000. Accounting for ruminal deficiencies of nitrogen and branched-chain amino acids in the structure of the Cornell Net Carbohydrate and Protein System. Proceedings of Cornell Nutrition Conference for Feed Manufacturers, Rochester, NY, pp. 224-238

Tylutki T.P., Fox D.G., Durbal V.M., Tedeschi L.O., Russell J.B., Van Amburgh M.E., Overton T.R., Chase L.E., Pell A.N., 2008. Cornell Net Carbohydrate and Protein System: A model for precision feeding of dairy cattle. Anim. Feed Sci. Tech. 143, 174-202

Tylutki T.P., PAS, Dpl. ACAN, Fox D.G., Mcmahon M., 2004. Implementation of nutrient management planning on a dairy farm. Prof. Anim. Sci. 20, 58-65

Van Soest P.J., Robertson J.B., Lewis B.A., 1991. Methods for dietary fiber, neutral detergent fiber, and nonstarch polysaccharides in relation to animal nutrition. J. Dairy Sci. 74, 3583-3597

Xiong Y.Q., Bartle S.J., Preston R.L., 1990. Improved enzymatic method to measure processing effects and starch availability in sorghum grain. J. Anim. Sci. 68, 3861-3870

Zheng P.L., Zhang Z.G., Chen X.H., Tu Y.R., 1986. Bovine Breeds in China (in Chinese). China Agricultural Publishing Press, Beijing, pp. 31-66

Zhao J.S., Zhou Z.M., Ren L.P., Xiong Y.Q., Du J.P., Meng Q.X., 2008. Evaluation of dry matter intake and daily weight gain predictions of the Cornell Net Carbohydrate and Protein System with local breeds of beef cattle in China. Anim. Feed Sci. Tech. 142, 231-246 